\title{
STATIC TESTS OF CONSTRUCTIVE TIRES USING HYDRAULIC PRESS ON THE
} SOIL

Doi:http://dx.doi.org/10.1590/1809-4430-Eng.Agric.v35n5p886-893/2015

\section{THIAGO M. MACHADO ${ }^{1}$, KLÉBER P. LANÇAS ${ }^{2}$, MAURO B. DE OLIVEIRA JUNIOR ${ }^{3}$, JOSÉ A. ARTIOLI ${ }^{4}$, INDIAMARA MARASCA ${ }^{5}$}

\begin{abstract}
The power consumption and load capacity of agricultural machines have grown and the effects of pressure on the soil by tires have been still little investigated. In concern with sustainable development, the relationship machine-tire-soil must be in balance to give more consistency on the best use of tires for a given load. This study aimed to evaluate four tires of two constructive types, the bias belted tires and radial tires, both with respective rim diameters of 22.5 and 26.5 inches with variables measuring the footprint, elastic deformation, sinkage and resistance to penetration. A hydraulic press with an attachment shaft for tire mounting and a box of soil in which the tire has been imposed on a load of $53.00 \mathrm{kN}$ using nominal pressures recommended by the tire manufacturer. The radial construction tire with rim diameter of 26.5 inches obtained less sinkage and resistance to penetration; however, greater elastic deformation and footprint compared to other tires. The bias-belted tire with 22.5-inch rim presented the highest resistance to penetration and the lowest elastic deformation.
\end{abstract}

KEYWORDS: compaction, footprint, pressure, elastic deformation, sinkage.

\section{ENSAIO ESTÁTICO DE TIPOS CONSTRUTIVOS DE PNEUS AGRÍCOLAS UTILIZANDO PRENSA HIDRÁULICA SOBRE SOLO}

RESUMO: A potência e a capacidade de carga das máquinas agrícolas vêm crescendo, e os efeitos da pressão imposta no solo, por meio dos pneus, ainda são pouco estudados. Com o desenvolvimento sustentável, a relação máquina-pneu-solo deve ser criteriosamente avaliada para que haja um melhor equilíbrio entre esses elementos. Este trabalho teve por objetivo avaliar quatro pneus com dois tipos construtivos: o diagonal cinturado BPAF (Baixa Pressão e Alta Flutuação) e o radial, ambos com diâmetros de aro de 572 e $673 \mathrm{~mm}$, sendo determinadas as seguintes variáveis: área de contato pneu/superfície da amostra do solo, deformação elástica do pneu, recalque e resistência mecânica à penetração da amostra em caixa de solo. Foi utilizada uma prensa hidráulica que possuía um eixo de fixação para montagem dos pneumáticos e uma caixa de solo na qual o pneu foi prensado com uma carga de $53,00 \mathrm{kN}$, utilizando as pressões nominais recomendadas pelo fabricante dos pneumáticos. O pneu de construção radial, com diâmetro de aro $673 \mathrm{~mm}$, obteve menores recalque e resistência à penetração, maior deformação elástica e área de contato em relação aos demais pneumáticos, enquanto BPAF, aro $572 \mathrm{~mm}$, apresentou a maior resistência à penetração e a menor deformação elástica.

PALAVRAS-CHAVE: compactação, área de contato, pressão, deformação elástica, recalque.

\footnotetext{
${ }^{1}$ Eng $^{\mathrm{o}}$ Agrícola, Prof. Doutor, Instituto de Ciências Agrárias e Ambientais, UFMT/Sinop - MT, Fone: (66) 8147-8311, tmmachado@ufmt.br

${ }^{2}$ Eng $^{\mathrm{o}}$ Mecânico, Prof. Doutor, Departamento de Engenharia Rural, UNESP/Botucatu - SP, kplancas@ fca.unesp.br

${ }^{3}$ Tecnólogo Mecânico, Gerente, Trelleborg/Santana do Parnaíba - SP, mauro.oliveira@ trelleborg.com

${ }^{4}$ Tecnólogo em M. Agrícola, Consultor, Trelleborg/Santana do Parnaíba - SP, jose.artioli@trelleborg.com

${ }^{5}$ Eng ${ }^{\circ}$ Agrônoma, Doutora em Agronomia, Pós Doutoranda do Departamento de Produção e Melhoramento Vegetal - Agricultura, UNESP/Botucatu - SP, marasca_7@ @otmail.com 


\section{INTRODUCTION}

The increased load capacity of transport equipment towed and mounted on trucks for sugarcane and grains has led to an increment of the pressure that is transferred to soil, causing compaction of layers and interfering in crop yield.

In recent years, the loads on undercarriages have been increasing, especially in self-propelling machines. The industry of agricultural machines and tires responds to this fact with the development and optimization of undercarriage new concepts such as radial tires of high flotation and shafts in "tandem" system, contributing to minimize the impacts of high loads on soil and reducing the risk of compaction (GEISCHEDER et al., 2011).

Soil compaction by agricultural machines has increased because the weight of machines has drastically grown in the last 30 years. These machines associated with agricultural practices present enough load to compact the soil, especially in conditions of high water content during operations of growing, planting or harvesting. These associations can cause rill formation in the trajectory of the undercarriage with soil, which is called "sinkage", contributing to its compaction. As consequence, a reduction in plant growth is observed and in the long-term, there is a risk of accelerated degradation of superficial layers and subsoil, contributing to the imbalance of ecosystems (MOHSENIMANESH \& WARD, 2007).

CAVALIERI et al. (2009) assessed the effects of a seeder tractor set pressure on soil physical properties, in which treatments evaluated pressure absence, low loads, high loads and the pressure caused by tractor wheels under a tire inflation pressure of $120 \mathrm{kPa}$. For that, these authors used sensors located at different soil layers, with water content varying between 0.16 and $0.21 \mathrm{~kg} \mathrm{~kg}^{-1}$, and determined that the load applied by the tractor on soil presented higher values of density and resistance to penetration on grounds of the higher pressures applied on it.

The term "footprint" refers to the tire area that stays in contact with the soil-supporting surface, and is an important indicator of the distribution capacity from the tire to the contact surface. Besides that, in the area that the efforts between tire and soil are transmitted (WULFSOHN, 2009). The determination of footprint between tire and soil plays an essential role in compaction intensity. The footprint estimate of tire contributes for the determination of contact pressures, tensionpropagation and potential risk of compaction that, for its turn, affects crop productivity. The traction between tires and soil can be increased through a raise in contact area. Additionally, the fuel consumption of tractors is dependent of the resistance to rolling which, for its turn, depends on the footprint between soil and tire (TAGHAVIFAR \& MARDANI, 2012).

Several actions to minimize the harmful effects of compaction have been suggested, such as an increase of diameter and width of tires, mounted wheels, better weight distribution of machines, lower pressure of tire inflations and restriction of traffic in areas with high water content (LANÇAS \& UPADHYAYA, 1997).

The employment of tires with greater diameter and same width generates greater footprint, once the length of footprint is directly proportional to its diameter. Previous studies about tires were conducted with compounds of technologies that are different from the ones that we have nowadays. Tests of tires of different constructive types: radial, diagonal and bias-belted LPHF (Low Pressure and High Fluctuation) assist the industry in finding improvements in structure and compounds, searching for technologies that are more suitable for the reality of consumers. In this sense, the agricultural sector demands updated technical results in order to guide the best option of investment in undercarriages that reduce the effect of soil compaction and that contribute to greater productivity. Thus, the aim of this study was to evaluate the cone index to soil penetration, to tire/soil contact area, to elastic deformation and the sinkage enabled by bias-belted (LPHF) and radial tires. 


\section{MATERIAL AND METHODS}

The experiment was conducted in the Test Nucleus of Agro-Forestry Machines and Tires, of the Rural Engineering Department of the Agricultural Sciences Faculty - UNESP, Botucatu Campus, SP. For the determination of studied variables of tires, a hydraulic press and a box of soil (Figure 1) were used according to the described by (MAZETTO et al., 2004). The box was filled with sample of a soil classified as RED LATOSOL (RL), according to EMBRAPA (1999), with $35 \%$ of clay, $62 \%$ of sand and $3 \%$ of silt, presenting water content of $0.10 \mathrm{~kg} \mathrm{~kg}^{-1}$, divided in four layers of $0.10 \mathrm{~m}$ of height. After filling each box layer, a road roller was used to level and compact the soil with an average density of $1.4 \mathrm{~kg} \mathrm{dm}^{-3}$.

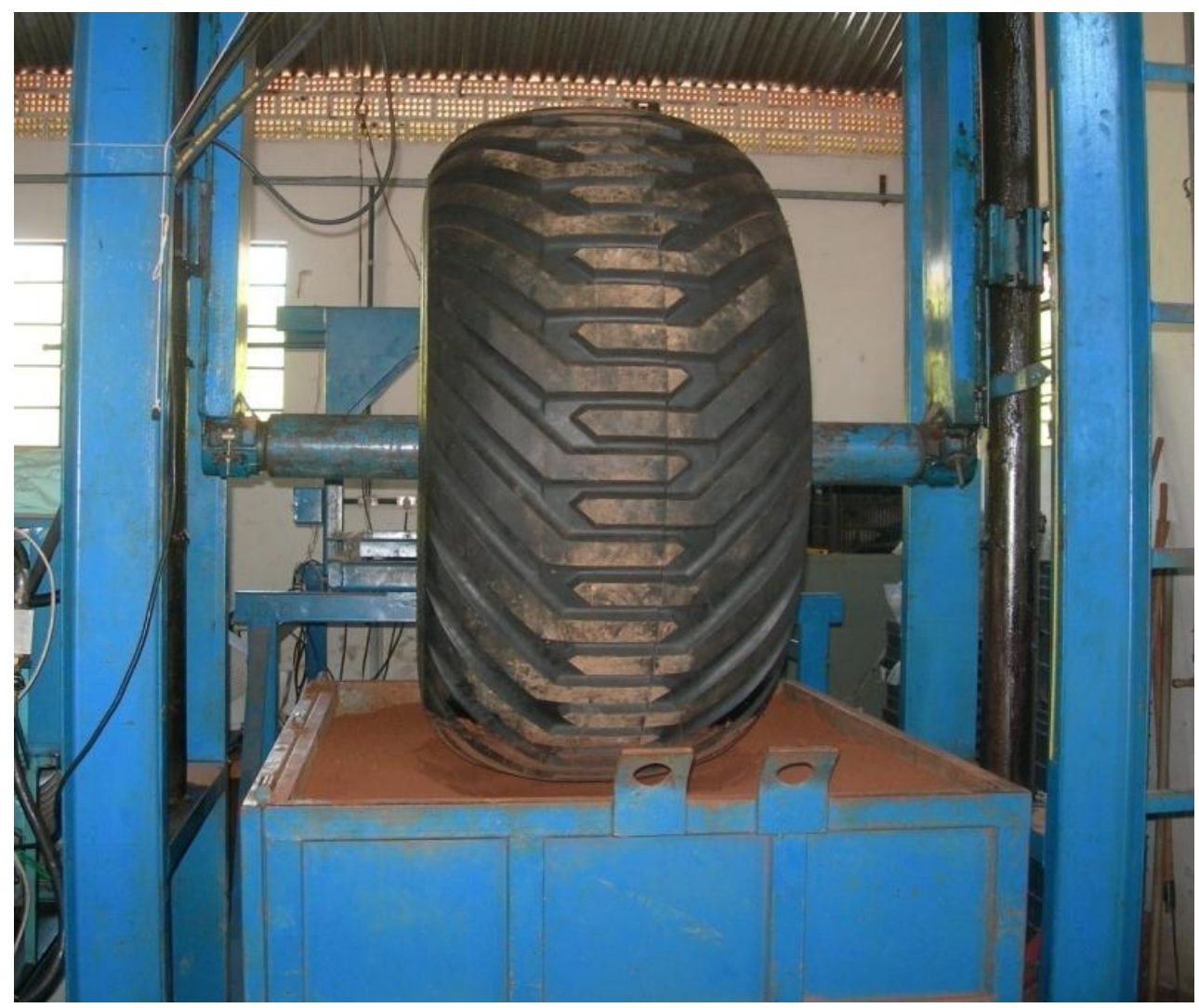

FIGURE 1. Hydraulic press pressing the tire onto the box of soil

Four different types of tires were used being two bias-belted tires of low pressure and high fluctuation - LPHF (600/55-26.5 and 600/50-22.5), and two of radial construction (600/55R26.5 and 600/50R22.5), both of Trelleborg brand (Figure 2).

The load applied on tires was defined based on the average load of $53.00 \mathrm{kN}$ per tire, from data collected in 10 weightings conducted in the Ferrari plant, (Porto Ferreira/SP unity) and Raízen plant (Barra Bonita/SP unity), obtained in transshipment trucks of two rear axle, loaded, with liquid capacity of $117.70 \mathrm{kN}$ and $32 \mathrm{~m}^{3}$ of volumetric capacity. The pressures were defined according to the manufacturer tables (TRELLEBORG, 2013). 


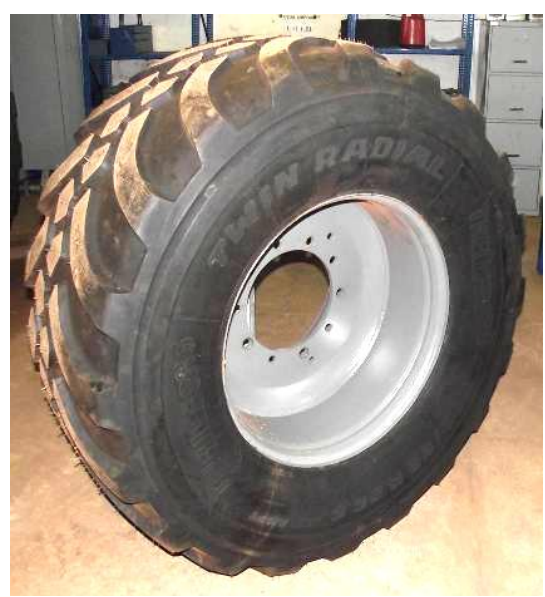

(a)

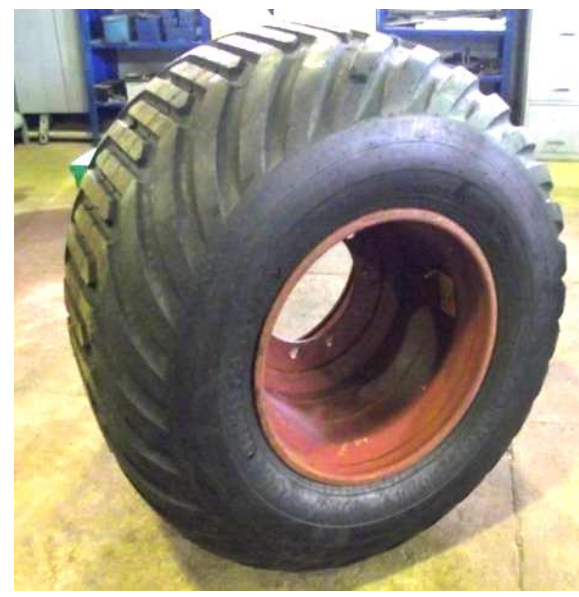

(c)

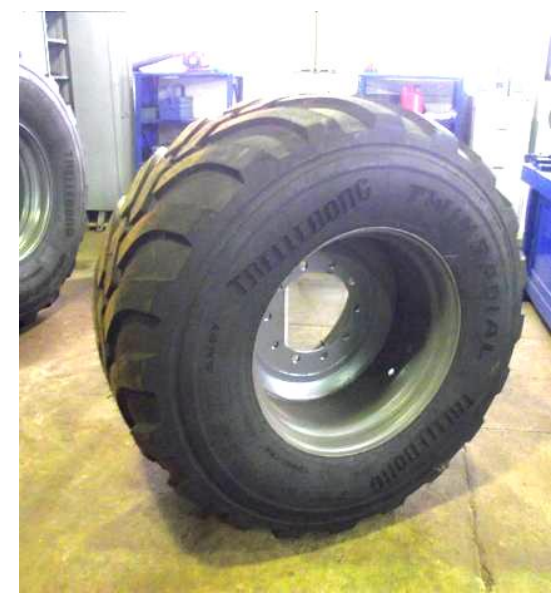

(b)

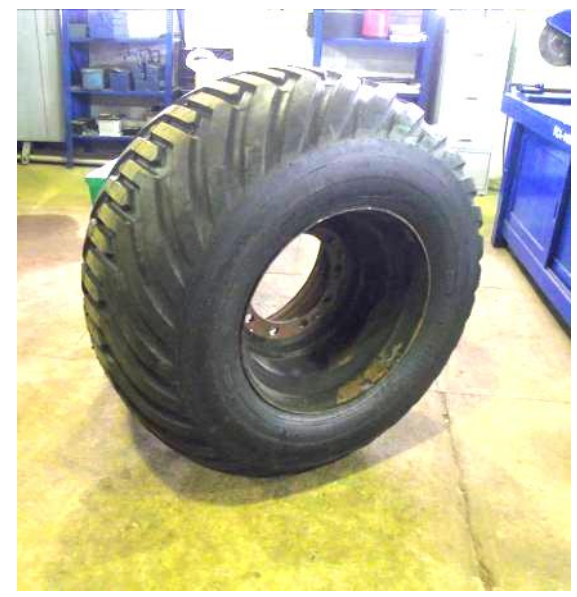

(d)

FIGURE 2. Tread design of radial construction tires, with measurements 600/55R26.5 (a) and 600/50R22.5 (b), tread design of bias-belted tires (LPHF), measurements 600/55-26.5 (c) and 600/50-22.5 (d)

TABLE 1. Dimensions, treatments of experiment, pressures of inflation and loads used in test.

\begin{tabular}{cccc}
\hline Dimensions & Treatment & Pressure of inflation $(\mathrm{kPa})$ & Load $(\mathrm{kN})$ \\
\hline 600/50-22.5 & D1 & 344.75 & 53.00 \\
600/50R22.5 & R1 & 344.75 & 53.00 \\
600/55-26.5 & D2 & 241.32 & 53.00 \\
600/55R26.5 & R2 & 241.32 & 53.00 \\
\hline
\end{tabular}

Each tested tire was placed in the press shaft and through the hydraulic system, loads were applied (Table 1) obtaining the printing of tire tread and the sinkage on the deformable surface. After each pressing, images of each footprint were obtained using a digital photographic camera sustained on a fixed platform and elevated in a hydraulic press structure.

The digital images were transferred to a microcomputer and the graphic readings of these footprints were obtained using the AUTOCAD ${ }^{\circledR}$ computer program, with the areas adjusted employing the relation expressed on [eq. (1)] (MAZETTO et al., 2004)

$$
\text { At }=\frac{\text { Asb Ati }}{\text { Asbi }}
$$

where,

At - area of tire $\left(\mathrm{m}^{2}\right)$;

Asb - area of soil box $\left(\mathrm{m}^{2}\right)$; 
Ati - area of tire on image $\left(\mathrm{m}^{2}\right)$,

Asbi - area of soil box on image $\left(\mathrm{m}^{2}\right)$;

In order to evaluate sinkages in soil box, a profilometer that presented $0.95 \mathrm{~m}$ of width, 1.95 $\mathrm{m}$ of length and stems with $0.38 \mathrm{~m}$ of length were employed. The profilometer presented 17 stems on its length and 13 on its width, with $0.15 \mathrm{~m}$ of distance from one another, with the same engaged to the structure of the soil box. The sinkage was obtained through difference of height between the stem located in the center of contact area and the external of the same, without deformation. The total deformations consisted of the sum of tire deformation and sinkage of pneumatic tires on soil, due to deformable surface in which the tires were pressed, following the adopted loading procedures, with the respective combinations of inflation pressures for each tire. For the determination of total deformations, a graduated scale was engaged to the structure of hydraulic press. The sinkage of tire was obtained through the difference in graduated scale of the value displayed without load and the value with the tested load applied from tire to soil box.

After each pressing of tire onto the soil sample, the resistance of soil to penetration was determined (cone index) using an electronic penetrometer with the acquisition and storage of data conducted by the NITAQ 6009 data collector. The resistance of soil to penetration in the contact area tire/sample of soil and externally to control was evaluated, with the aim to obtain the increment of soil resistance to penetration of each contact of tire after going through loads imposed by press. Twelve points were measured obtaining the values of cone index in six points lengthwise in the central line of tire pressing, altering claws and between claws of tires and six points transversally at a distance of $0.10 \mathrm{~m}$ between each perforation in the area of greatest sinkage of tires. In the interest of determining the values of increment to soil compaction, four random perforations were conducted outside the place of soil deformation (control).

The experiment was conducted under a completely randomized design, with four repetitions. The obtained data were submitted to comparison of means, by the Tukey test, at $5 \%$ of probability.

\section{RESULTS AND DISCUSSION}

The values for tire-soil footprints, elastic deformation, sinkage and increment of resistance of soil to penetration of tires are presented on Table 2 .

TABLE 2. Results of average variables measured in tests of tires.

\begin{tabular}{cccccc}
\hline Treatments & $\begin{array}{c}\text { Footprint } \\
\left(\mathrm{m}^{2}\right)\end{array}$ & $\begin{array}{c}\text { Dif. of footprint in } \\
\text { relation to R2 }(\%)\end{array}$ & $\begin{array}{c}\text { Elastic } \\
\text { deformation of } \\
\text { tires }(\mathrm{m})\end{array}$ & $\begin{array}{c}\text { Sinkage of } \\
\text { tires }(\mathrm{m})\end{array}$ & $\begin{array}{c}\text { Increment of resistance of } \\
\text { soil to penetration }(\mathrm{MPa})\end{array}$ \\
\hline $\mathrm{R} 2$ & $0.530 \mathrm{~A}$ & - & $0.081 \mathrm{~A}$ & $0.086 \mathrm{C}$ & $0.685 \mathrm{D}$ \\
$\mathrm{D} 2$ & $0.529 \mathrm{~A}$ & -0.188 & $0.063 \mathrm{~B}$ & $0.154 \mathrm{~B}$ & $1.185 \mathrm{C}$ \\
$\mathrm{R} 1$ & $0.454 \mathrm{~B}$ & -14.339 & $0.044 \mathrm{C}$ & $0.165 \mathrm{AB}$ & $1.228 \mathrm{~B}$ \\
$\mathrm{D} 1$ & $0.448 \mathrm{~B}$ & -15.471 & $0.029 \mathrm{D}$ & $0.166 \mathrm{~A}$ & $1.530 \mathrm{~A}$ \\
\hline
\end{tabular}

In each column, for each factor, means followed by the same uppercase letter do not differ statistically from each other, by the Tukey test, at $5 \%$ of probability.

The treatments R2 and D2 presented greater footprint in comparison to others (Table 2) and did not differ from each other, as treatment R1 presented a footprint 14\% lower and treatment D1 presented footprint $15 \%$ lower compared to R2.

The lowest increments of soil resistance to penetration were obtained in treatment $\mathrm{R} 2$. Regarding treatment D1, the greatest resistance to penetration of soil sample was found. The treatment R1 obtained the greatest deformation and the lowest increment of resistance to penetration when compared to treatment D1, of same rim diameter.

Although all tires present the same width of treads without load, the diameter of tires in treatments R2 and D2 were greater than in the other treatments, presenting a load capacity higher 
than others do. This enabled the use of an inflation pressure lower than other treatments, increasing contact area printing in width and length (Figure 3), for greater elastic deformation and consequently lower sinkage and increment of soil resistance to penetration (Table 2).

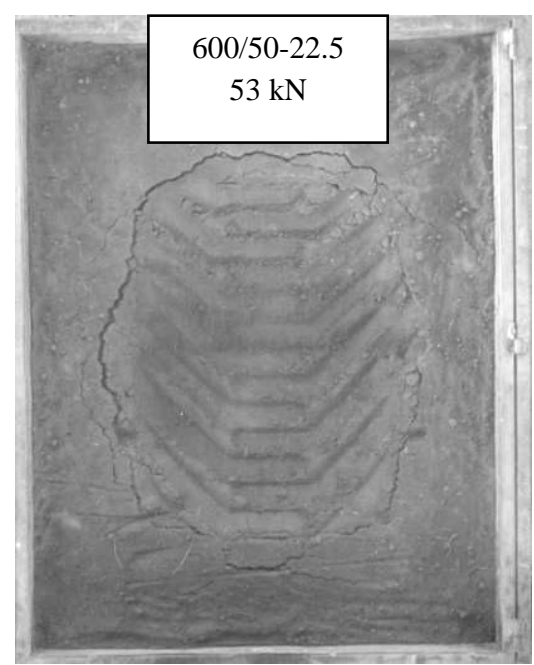

(a)

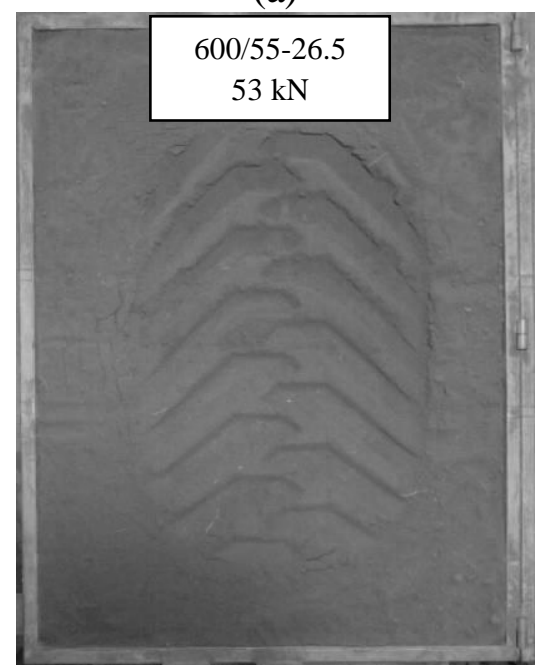

(c)

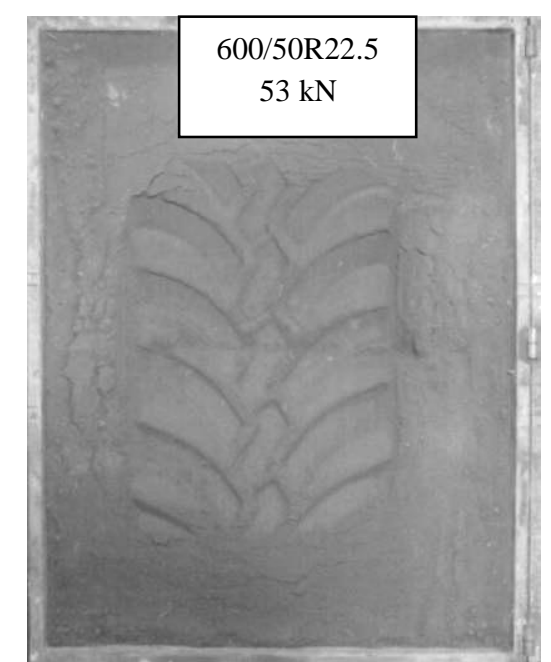

(b)

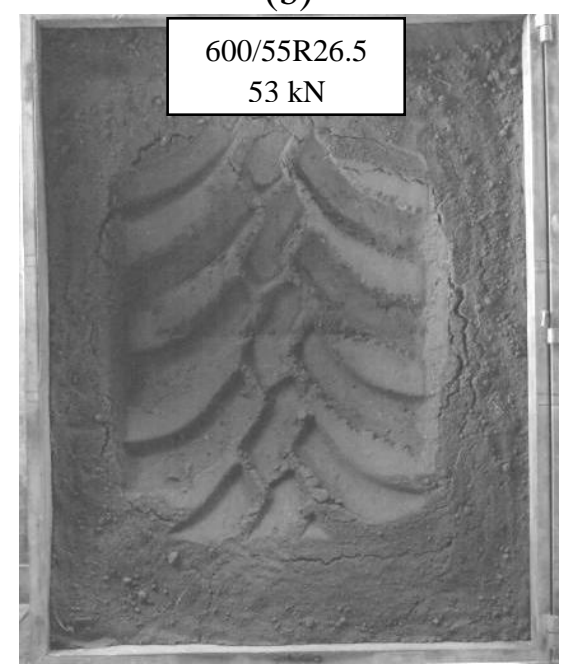

(d)

FIGURE 3. Printing of tires 600/50-22.5 (a) 600/50R22.5 (b) 600/55-26.5 (c) 600/55R26.5 (d) pressed on soil box.

The results achieved in this study corroborate with the obtained by BOTTA et al. (2008) who compared four tires of different measurements, diagonal and radial, and the results demonstrated lower increment of resistance to penetration for tires of radial construction. In tests conducted with diagonal and radial tires, applying several loads and pressures, ALMEIDA et al. (2010) also obtained greater footprint and lower resistance to penetration for radial tire.

HARRIS \& RETHMEL (2011) testing radial tires of different widths, diameters and constructive technologies, observed that tires working with low pressures obtained results with 7.5 to $12.6 \%$ of increment in footprint.

According to the demonstrated on Figure 4, the controls indicated insignificant value variations, the treatment $\mathrm{R} 2$ presented Cone index below 2.0 $\mathrm{MPa}$, indicating that in superficial layers, the tire of greatest diameter and radial construction obtained the best results. The treatment D1 presented Cone index of $2.83 \mathrm{MPa}$ at depth of $0.10 \mathrm{~m}$, which was the greatest value, obtained among all treatments and the treatment R1 did not reach values above 2 MPa. SILVA et al. (2002) stated that a value of $2.0 \mathrm{MPa}$ of Cone index has been associated with disabling conditions for root growth, damaging the aerial part of plants. 
The results evidenced and confirmed that the right use of constructive types and models of tires minimize soil compaction, supporting data obtained by LANÇAS \& UPADHYAYA (1997).

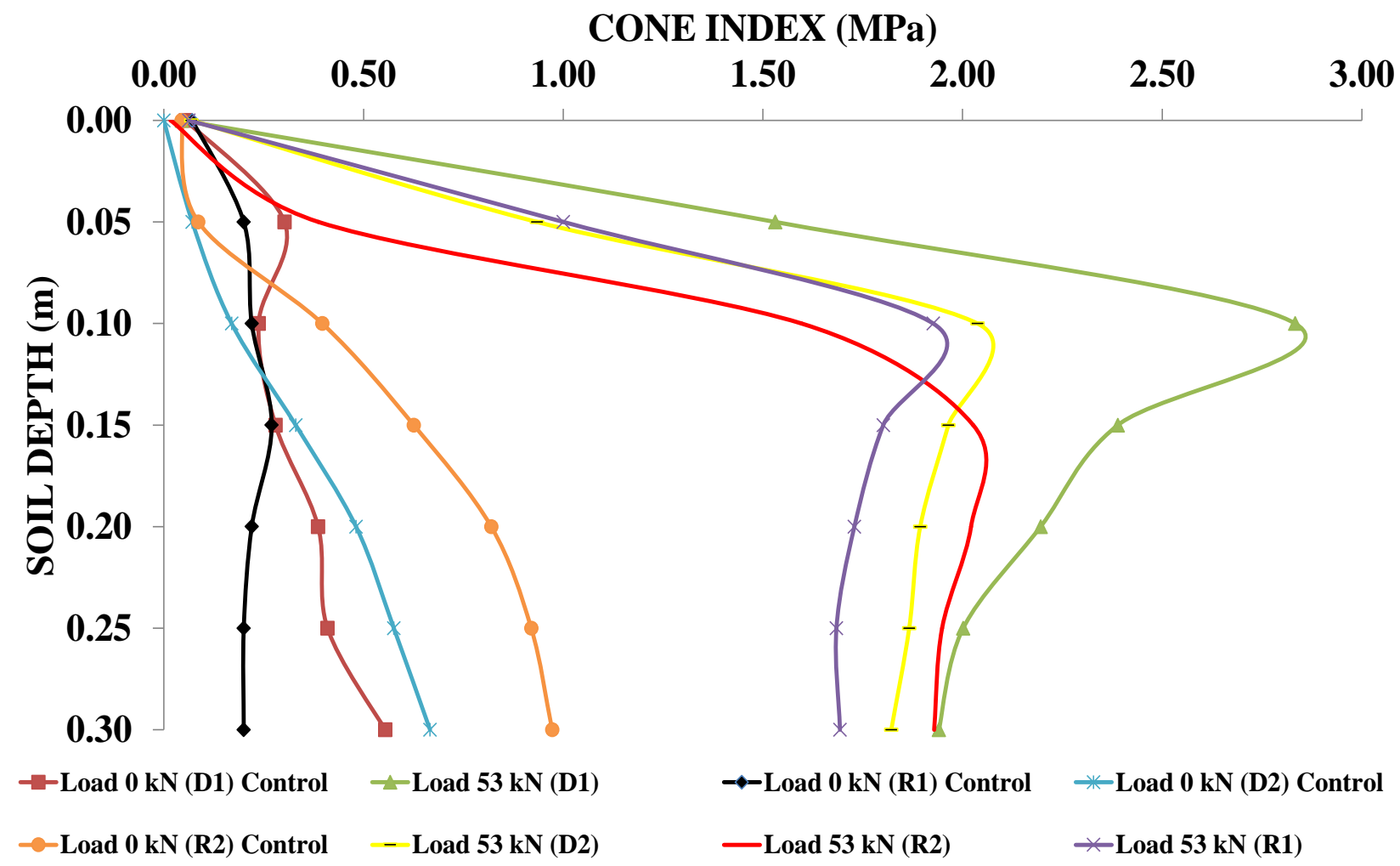

FIGURE 4. Values of cone index for the treatments D1, R1, D2 and R2 in relation to depth in soil box.

\section{CONCLUSIONS}

The rims with the greatest diameters presented the best results. The tire of radial construction, and rim diameter of 26.5 inches was highlighted presenting the greatest footprint, the greatest elastic deformation and the lowest sinkage of sample in soil box and, consequently, contributing to minimize the effects of compaction, evaluated by the resistance of soil to penetration. The biasbelted tire (LPHF) and rim of 22.5 inches obtained the highest increment of resistance to penetration of soil sample and the lowest elastic deformation.

\section{ACKNOWLEDGEMENT}

To TRELLEBORG of Brazil for granting the tires for tests and the NEMPA.

\section{REFERENCES}

ALMEIDA, M. L.; MASIERO, F. C.; LANÇAS, K. P.; GUERRA, S. P. S.; JESUS, M. G. Avaliação de pneus para carretas transbordo em tanque de solo. Revista Científica Eletrônica de Agronomia, Garça, v.17, n.1, p.7-16, 2010.

BOTTA, G. F.; RIVERO, D.; TOURN, M.; MELCON, F. B.; POZZOLO, O. Soil compaction produced by tractor with radial and cross-ply tyres in two tillage regimes. Soil and Tillage Research, New York, v.101, n.3, 2008. Disponível em: <http://www.sciencedirect.com/science/article/pii/S0167198708000974>. Acesso em: 26 jan. 2013. 
CAVALIERI, K. M. V.; SILVA, A. P.; ARVIDSSON, J.; TORMENA, C. A. Influência da carga mecânica de machine sobre propriedades físicas de um cambissolo háplico. Revista Brasileira de Ciência do Solo, Viçosa, MG, v. 33, n.3, p.477-485, 2009.

EMBRAPA - EMPRESA BRASILEIRA DE PESQUISA AGROPECUÁRIA. Centro Nacional de Pesquisa de Solos. Sistema brasileiro de classificação de solos. Rio de Janeiro: CNPS, 1999. 412 p.

GEISCHEDER, R.; BRANDHUBER, R.; DEMMER, M. Effects on soil structure caused by different undercarriages with the same contact pressure. St. Joseph: ASABE, 2011. 8p. (Paper No. 1111203)

HARRIS, B. J.; RETHMEL, B. R. Comparison of IF and standard marked metric radial ply tires. St. Joseph: ASABE, 2011. 12p. (Paper No. 1110804)

LANÇAS, K.P.; UPADHYAYA, S. K. Pneus radiais para tratores: guia para seleção correta da pressure de inflação. Energia na Agricultura, Botucatu, v.1, n.1, p.1-33, 1997. (Boletim Técnico).

MAZETTO, F. R.; LANÇAS, K. P.; NAGAOKA, A. K.; CASTRO NETO, P.; GUERRA, S. P. S. Avaliação do contato pneu-solo em três modelos de pneus agrícolas. Engenharia Agrícola, Jaboticabal, v.24, n.3, p.750-757, 2004.

MOHSENIMANESH, A.; WARD, M. S. On-the-move monitoring of soil-tyre interaction on soft soil, using wireless data acquisition. Transactions of the ASABE, St. Joseph, v.50, n.6, p.1919-1925, 2007.

SILVA, A. P.; TORMENA, C. A.; IMHOFF, S. Intervalo hídrico ótimo. In: MORAIS, M. H.; MULLER, M. M. L.; FOLONI, J. S. S. Qualidade física do solo: métodos de estudo - sistemas de preparo e manejo do solo. Jaboticabal: Funep, 2002. p.1-20.

TAGHAVIFAR, H.; MARDANI, A. Contact area determination of agricultural tractor wheel with soil. Cercetari Agronomice in Moldova, Lasi, v.45, n.2, p.15-20, 2012. Disponível em: <http://www.uaiasi.ro/CERCET_AGROMOLD/CA2-12-02.pdf>. Acesso em: 26 jan. 2013.

TRELLEBORG. Agricultural tyres manual. 2013. 298 p.

WULFSOHN, D. Soil-tire contact area. Transactions of the ASABE, St. Joseph, v.3, n .3, p. 59-84, 2009 